\title{
Indonesia's Multi-track Diplomacy toward Palestine: Indonesian Society's Supports for Palestinian in the Social, Education, and Cultural Aspects
}

\author{
${ }^{1}$ Libasut Taqwa, and Muhammad Luthfi Zuhdi ${ }^{2}$ \\ ${ }^{1}$ Postgraduate Student of Politics and International Relations in Middle East, Universitas Indonesia \\ ${ }^{2}$ Associate Professor, Postgraduate School of Middle East Studies, Universitas Indonesia, Indonesia
}

\begin{abstract}
Indonesian Muslim people are $87.2 \%$ from the approximately 250 million inhabitants. This led Indonesia into a country with a majority Muslim population in the world. The problems and the future of Palestine were the regular topic discussed at the meetings of Islamic Organizations in Indonesia. Eventually, the Indonesian Muslim community formed institutions and organizations to assist the people of Indonesia to accommodate the Palestinian and the issues of Palestinian independency.

According to that situation, Indonesian society as non-state actors has initiated the numbers of cooperation in various fields, such as the establishment of the hospital and providing medicine supplies, awarding scholarships in the field of health and business for orphans from elementary to college level. In addition, some cultural cooperation was held in order to introduce the Palestinians' problems. It can be seen from the efforts of The Institute of Democracy and Education (IDE) when the Palestinian cultural exhibition was held few times ago which showed the interest of Indonesian society in strengthening the cooperation with Palestine.

This study aims to see the effectiveness of the multi-track diplomacy that has been built by non-state actors in order to improve non-political cooperation between Indonesian society with the Palestinians. In addition, research also wants to answer how cooperation in social, education, and culture can promote the issue of Palestinian independence in the international areas.
\end{abstract}

Keywords: Social, Education, Cultural supports, non-state actor, multi-track

\section{Introduction}

Since the conflict with Israel established, Arab countries and the Palestinians are yet recover from Nationalism turmoil and the fall of the Chaliphate. The Arab coalition then responds with attacks and military interventions into Israel occupied territory and reached its culmination in 1967. But the war had been won by the Israeli and repelled the Arab countries. The failure of the Arab countries in that war then caused the growth of the movement for Palestinian independence by the Palestine Liberation Organization (PLO). The conflict continues to roll until the late 1960s and early 1970s, some Palestinian military groups launched various waves of attacks against Israelis all over the world. Since then the conflict between Israel and Palestine more pointed and until now have not found the right resolution for both parties. At least, there are several factors that make peace and reconciliation between both sides is difficult to be realized (Sihbudi 2007, 318-319). First, the peace agreement between the two sides so far have not also be able to find a sustainable resolution, especially in the field of implementation of the resolution.

For example, many treaties and peace conferences since the Oslo agreements to the Annapolis which is difficult to achieve because of the deadlock approach of two sides to seek peace. Even if an agreement is reached, there were no an improvement on implementation. The second, the absence of a conflict mediator who truly willing to resolve the conflict completely. In this case, the United States that has several times acted as a mediator can be said to be less serious in a role to mediate the conflict involving Israel and the Palestinians. Third, the reign of the Likud political party in Israeli government. The achievement of conflict resolution in the history of two sides becomes difficult, when the Likud won the election, and it is extremely difficult to peace achievement, because Likud was well known as opposition to the establishment of a Palestinian independence. Fourth, in internal Palestinian, they have divided into two authoritative regions, in West Bank and Gaza Strip. It is very difficult to get a comprehensive dialogue between these two regions (Beinin \& Hajjar 2014, 1). 
There are some consequences of that prolonged conflict since 1967. First, is the poor of educational quality of the Palestinian. According to UNESCO, from 2003 to 2005, there were more than 180 attacks launched by the Israeli army on Palestinian schools that have an impact on the deaths of 180 students and teachers. During that period, more than 1500 school disappeared by aggression. This fact is inversely proportional to Israel where the government spent an average of 2,300 Shekels for each Jewish student's educational development (www.seamac.org).

Educational discrepancies between two countries further exacerbate the Palestinian educational reality. A billions dollars of aid that given by the World Bank in 2012 (www.birzeit.edu), only a few of which are earmarked for building infrastructure and increased the education quality because each of grant, in addition to obstructed by Israel boycott, depleted human costs absorbed and other infrastructure. Second, in social aspect. The gap within the social development has been achieved time after time. After the al-Aqsha Intifada, since 2000, More than $22 \%$ of children under the age of 5 suffer from malnutrition, including $9.3 \%$ suffering from acute malnutrition, $13.2 \%$ suffering from chronic mal-nutrition and $15.6 \%$ suffering from acute anemia. It is expected that this will lead to long-term negative effects on the physical and cognitive development of many of these children. More than half of Palestinian families eat one meal a day only. Food consumption in Palestinian families dropped by 25-30\% per person, especially protein intake. The number of Palestinians living under extreme poverty multiplied threefold since the beginning of the Al-Aqsa Intifada (Palestinian Centre for Human Rights 2006, 5).

In cultural side, there are some destructive actions after 2004. Many Palestinian have lost their cultural heritage both physical and non-physical aspects. Whereas, culture as important as education, is one of the great point for the Palestine independent campaign in international forum. In the meantime, Indonesia as a Muslim country, has officially contributed to and supported Palestine. The relations between Islam in Indonesia and their implications for the country's foreign policy have attracted considerable attention since the independence of Indonesia. But the aids, support, and cooperation with the palestinian, are not only limited to formal diplomatic channels. Non-formal approach, as a part of multi-way diplomacy driven by non-governmental components, provides greater opportunities in supporting Palestine. Humanitarian agencies in Indonesia have showed continuous commitments in helping the Palestinians by preparing "capacity building" program, including the improvement of the quality of Palestine people in education, Social, and culture.

\section{Methodology and Literature Study}

\subsection{Research Methodology}

This study used a qualitative approach with content analysis method which attent to the content or contextual meaning of the text to analyse the data such as the sources of primary data collection review and research derived from books, articles, websites that are directly related to the Indonesian Society like NGOs, as well as secondary sources derived from books, journals, news and articles on the internet, as well as interview.

\subsection{Literature Study}

Diplomacy accros nations are not merely rely on the formal efforts from the government and state institutions (Bohmelt 2010, 167). However, elements of non-formal as individuals, community groups, nongovernmental organizations also have an important meaning in diplomacy as a mediator in conflict resolution and the development of relations between countries.

This research is conceptually uses a multi-track diplomacy which is built upon the division of Joseph Montville special concept of diplomacy in 1981 which seeks to reconcile diplomatic official in resolving conflicts (First track) with the efforts of non-governmental performed by professionals both within and between countries (Second track), (Notter 1996, 1). This concept was later developed after John Mcdonald expand the study of diplomacy by dividing it into several disciplines such as media, Conflict resolution professional, or Business who reconstructed phrases diverse diplomatic efforts into a multi-path, hence the birth of Multi-Track (Mcdonald, 2014, 4). Multi-Track diplomacy becomes a study of its own that puts at least nine diplomatic approaches were carried out non-state actors, including education as a way undertaken in the peace process and the development of Human Resources of a country that begins with an awareness that interaction of formal, official, as well as the interaction between the government with representatives designated by each state is not a 
method that will forever be effective in achieving international cooperation to resolve conflicts and create a mutual relationship.

In other words, Multi-track diplomacy means a conceptual effort that is used to review the international peace process as a living system. This concept includes a variety of interconnection activities between individuals, institutions, and communities that go hand in hand in a single overriding goal of world peace as a continuation of efforts to "track one" and "track two" diplomacy. The development of several tracks (Multi-track) of diplomacy demonstrates that conflict is a complicated phenomenon, requiring a multi-dimensional approach if it is to be effectively managed and resolved. Since each track of diplomacy has its own strengths and weaknesses, it is important to involve the multi-track diplomacy concept to improve the chances of resolving conflicts without loss of life and material (Mapendere, 2005, 74-75). Multi-track diplomacy represents one key set of foreign policy strategies which can be deployed to achieve development assistance for the people (Dudouet \& Dressler, 2016, 6) by non-state actor.

Education, Social, and culture, as the focus of this study, are a part of multi-track diplomacy that cultivated non-state actors in a non-formal relationship with the state or its citizens were the objectives of cooperation and diplomacy is beneficial to increase the capacity of productive generation resources of Palestinian by educational framework of world peace; including by reducing (resolving) conflicts and tensions and misunderstandings between groups or nations in preparing its independence especially with education approach.

\section{Indonesian Society's Support}

Since the independence, and after the 1955 Asian-African Conference in Bandung, Indonesian government formally helped to contribute the support for Palestine. Indonesia, as the biggest muslim's country has achieved some of foreign policy based on the religius issues. According to Anwar $(2010,37)$, which said that the relations between Islam in Indonesia and their implications for the country's foreign policy have attracted considerable attention in recent years especially for Palestine issues. Those efforts are not limited to mere formal diplomatic channels only. Non-formal approach, as a part of multi-way diplomacy that driven by non-governmental components give greater space in struggle for Palestine support. There seems to be continued commitment of humanitarian agencies in Indonesia to help the Palestinians to prepare the "capacity building" program for them including the improvement of the education, as well as social, and cultural qualities.

One of the non-governmental organizations in Indonesia that share concerns on education for the Palestinians is the Indonesian Red Crescent (BSMI). It is the only public institution in Indonesia that prioritizes education quality for the Palestinians. Palestine has become a concern for BSMI in its efforts to build humanitarian missions that cross borders of states and nations, while carrying the Indonesian flag and the Red Crescent emblem. Since 2002, BSMI has been sending groups of volunteers to the Middle East to provide medical aid and ambulance assistance to Palestine, Iraq, and other countries impacted by war and civil resistance (Direktorat Timur Tengah Kemenlu RI, 2014, 54). The aid programs are not limited to only physical development, but are also closely related to human resource capacity building through education and scholarships for Palestinians.

The establishment of the Palestinian Authority led to the rapid development of Palestinian social institutions. To a great extent, this built on the work of the many voluntary and non-governmental organizations that had sprung up during decades under occupation. From the ranks of these bodies - many of them supported by international charitable and social-development organizations - there quickly emerged a local leadership with the experience and skills needed to start fashioning the institutions of civil society (United Nation 2008, 72). The BSMI completely aware this situation and encourage to have a good support to the Palestinian especially in educational side.

According to Ambari (2016), the establishment of the Indonesian Red Crescent was initiated during the social conflicts in Ambon, Indonesia. At that time, several people with different backgrounds gathered in Jakarta to strive for social and humanitarian assistance for victims of the conflict, with primary focus in health, logistics and education. The group was formalized by Kiyai Haji Amidhan from the Indonesian Council of 'Ulema (MUI) with the vision of being a national humanitarian agency in Indonesia and working together with other humanitarian agencies at the national, regional and international level. The missions of the organization are: carrying out humanitarian and peacekeeping efforts, protecting lives during conflicts and other situations, 
preventing sufferings by improving and strengthening humanitarian laws and universal humanitarian principles, providing the best service for humanity and peace and collaborating with humanitarian agencies and other institutions at the national, regional, and international level in achieving its goals.

BSMI has finally garnered supports from educational institutions in Indonesia for the palestinian student or youth, such as Universitas Indonesia, Universitas Islam Negeri Jakarta, Universitas Gadjah Mada, Universitas Brawijaya, Universitas Solo, and Universitas Airlangga. These partnerships are carried out in sharing system, in which the Ministry of Education and Culture of the Republic of Indonesia covers the tuition fee, while BSMI, with the support of Indonesians, bear the living cost for the students. Now, Within 2010 to 2016, six students from Palestine -for medicine and engineering- have been continuing their education at universities in Indonesia. However, this opportunity is still limited to men only as female Gazan Palestinian students are having difficulties in adjusting themselves to Indonesian culture. Thus, we have to admit that educational diplomacy, as initiated by BSMI, is essential in improving human development capability, that is needed to enhance human security to compete in global competition (Sen 2002, 2). Education will create new paths and opportunities to enhance a nation's ability, to win the competition at global level, which may all lead to the welfare and prosperity of the society (Soesilowati 2015, 298).

Beside that, the cultural effort to support Palestine has been elaborate after the Institute of Democracy and Education (IDE) held a Palestine cultural night that attended by around 1000 people around indonesia. The event was held on December 15, 2015, which entitled "Palestinian Culture Night with ASAYEL Folklore Troupe." and attended also by the Secretary General of the Organization of Islamic Conference (OIC) Iyad Ameen Madani, Palestinian Ambassador Dr. Al Mehdawi, the Indonesian Foreign Minister Retno L. Marsudi, also Palestinian Foreign Minister Riyad al-Maliki. There were two activities to be implemented, the movies about Palestine's film, and the Palestinian cultural performances, including dancing and singing (theide.org).

The Institute of Democracy and Education (IDE) as a Non Government Organizations working in the field of democracy, education, religious, social, and cultural re-organizes recognize that Palestinian culture festival aims to introduce the Palestinians to the world's cultural diversity. Palestinian culture is one of the oldest cultures in the world that must be maintained. Palestinian cultural festival utilizing the cultural aspects of the Palestinian national interest in the constellation of the international community. Palestinian culture also as a tool to show the degree of civilization of a nation (theide.org). This is a technique exploiting the wealth dimension in the constellation of relations between nations. Palestinian cultural diplomacy should be distinguished from the use of culture outside the framework of foreign policy, for example, to the benefit of the Palestinian tourism. Palestinian cultural diplomacy should involve the power and authority of the political, economic, and military, and all of it is owned by the State of Palestine. Palestinian cultural diplomacy not only deal with political matters, especially foreign policy, but also with regard to other areas such as tourism and export trade.

In social aspect, Indonesian society have been allocated very much efforts to the palestinian infrastuctures, hospital, and the other side. many activities that have been conducted over the past ten years by Indonesian society such as building water installations in Khan Youmis that drain 100 hectares of agricultural land, reconstruction of schools in 2014, the development of food Bank program by Dompet Dhu'afa in Jabaliya that has been managed to distribute food package for 910 families, and in 2014, 50 orphans have been sponsored for 24 months a worth of $\$ 40$ per month (Direktorat Timur Tengah Kemenlu RI, 2014, 117-124)

Educational, cultural, and social diplomacy, as a multi-track, are believed to have enhanced mutual understanding, mutual interest, mutual respect and mutual trust (Asia Pulse, 2011) between the Palestinians and Indonesians. This approach is an effective strategy in an effort to foster mutual concern and common interest. One of the reasons is that cultural and educational diplomacy will have a positive effect in embracing the "heart and mind" of a nation (Nye, 2004, 256).

Additionally, this approach will foster a sense of togetherness between the citizens of Indonesia and Palestine and has also become a strategic concept in soft power diplomacy that wield official influence for the government, such as: (1) increasing the "attractiveness" of Indonesian government, which will increase the interest and bond between the people and the government of Indonesia because, in many cases, there are discrepancies between the government's foreign policy and the people's expectation; (2) creating opportunities for Indonesian government for better bargaining position in expanding its influence, particularly within the Islamic society and the Middle East, in terms of developing education for colonized countries; (3) receiving 
helps and supports from the Indonesian citizens to improve the quality of education in other countries, in this case the Palestine, which will raise Indonesian prestige in foreign relations and diplomacy.

\section{Conclusion}

The explanation of multi-track diplomacy above further elaborates the significance of non-state actors in diplomatic efforts in social, education, and culture aspect for the colonized Palestinian. By multi-track public diplomacy, therefore, the opportunity for Palestine people to have a good hope for the future will become more better than before. In addition, the official sector have to aware that diplomacy is not monopolized by elite officials from the Ministry of Foreign Affairs or the Ministry of Education and Culture anymore, but also the public or stakeholders actively, such as the NGOs, professionals and also university students, as they can especially focus on issues that are more related to the needs of public and to non-political diplomacy approach.

Diplomacy therefore has to be able to accommodate non-state actors and promote human resources development as the main issue in international relation. In multi-track diplomacy, achieving mutual interests and benefits among the actors is a must. The ability to understand the interests and priorities of citizens, especially Palestinians as the partner in this diplomatic process, is very significant because this is essentially a trade-off of interests between the actors.

\section{References}

[1] Asia Pulse. (2011). Indonesia to Use Education as Cultural Diplomacy with US, 5 April.

[2] Beinin, Joel \& Lisa Hajjar. (2014). Palestine, Israel and the Arab-Israeli Conflict; A Primer. The Middle East Research \& Information Project

[3] Bohmelt, Tobias. (2010). The Effectiveness of Tracks of Diplomacy Strategies in Third-Party Interventions. Journal of Peace Research; Peace Research Institute Oslo, pp. 167-178. DOI: 10.1177/0022343309356488. Available: sagepub.co.uk/journalsPermissions.nav jpr.sagepub.com

https://doi.org/10.1177/0022343309356488

[4] Direktorat Timur Tengah Kemenlu RI. (2014). Bantuan Kemanusiaan Indonesia Untuk Palestina. Jakarta: CV. Hilda

[5] Dudouet, Véronique \& Matteo Dressler. (2016). From Power Mediation to Dialogue Facilitation: Assessing the European Union's Approach to Multi-Track Diplomacy. Germany: Berghof Foundation. Available: www.woscap.eu

[6] Fortuna, Anwar Dewi. (2010). Foreign Policy, Islam and Democracy in Indonesia. Journal of Indonesian Social Sciences and Humanities Vol. 3, 2010, pp. 37-54. Available; http://www.kitlv-journals.nl/index.php/jissh/index.

[7] James notter \& Louise Diamond. (1996). Building Peace and Transforming Conflict: Multi-Track Diplomacy in Practice. Occasional Paper Number 7: The Institute for Multi-Track Diplomacy.

[8] Mapendere, Jeffrey. (2005). Track One and a Half Diplomacy and The Complementarity of Track. COPOJ - Culture of Peace Online Journal, 2 (1), pp. 66-81. ISSN 1715-538X. Available: www.copoj.ca

[9] McDonald, John W. (2014). Multi-Track Diplomacy: A Positive Approach to Peace. Washington DC: Institute for Multi-Track Diplomacy

[10] Nye, Joseph S. Jr., (2004). "Soft Power and American Foreign Policy”, Political Science Quarterly 119 (2); The Academy of Political Science, pp. 255-270

https://doi.org/10.2307/20202345

[11] Palestinian Centre for Human Rights, Annual Report. 2006

[12] Sen, Amartya. (2002). "Basic Education and Human Security" Background paper for the workshop on Basic Education and Human Security." Jointly organized by the Commission on Human Security, UNICEF, the Harvard University, Kolkata, 2-4 January 2002.

[13] Sihbudi, Reza. (2007). Menyandera Timur Tengah. Jakarta: Mizan,

[14] Soesilowati, Sartika. (2015). "Diplomasi Soft Power Indonesia melalui Atase Pendidikan dan Kebudayaan" Jurnal Global \& Strategis Year 9 Number 2. Universitas Airlangga, pp. 293 - 308. ISSN 1907-9729. Available: http://journal.unair.ac.id/diplomasi-soft-power-indonesia-article-10289-media-23-category-8.html.

[15] Sukma, Rizal. (2011). Soft Power and Public Diplomacy; The Case of Indonesia. in Public Diplomacy and Soft Power in East Asia. Sook Jong Lee, Jan Melissen, Ed. Palgrave Macmillan Series in Global Public Diplomacy.

https://doi.org/10.1057/9780230118447_6 
[16] http://www.seamac.org/equalrights.htm, Retrieved on September 11, 2016

[17] http://www.birzeit.edu/en/blogs/palestinian-universities-under-occupation, retrieved on September 11, 2016.

[18] http://bsmi.or.id/id_ID/profile/history/, retrieved on September 08, 2016.

[19] https://theide.org/the-founding-of-the-ide/, retrieved on September 08, 2016.

[20] The Question of Palestine and The United Nation. New York: United Nation, 2008. Available: http://unispal.un.org/unispal.nsf.

[21] Interview with Djazuli Ambari, The Director of Indonesian Red Crescent, Lemhanas Building, Jakarta. September 16, 2016.

Many thanks to Mr. Muhammad Luthfi Zuhdi, Noorayni Rahmawati and Nadia Sarah Adzani for their help to have a very comprehensive disscussions and dialogues with me to complete this paper. 